\title{
The effect of acute and chronic insulin administration on insulin-like growth factor-I expression in the pituitary-intact and hypophysectomised rat
}

\author{
E.A.Salamon, J.Luo and L.J.Murphy \\ Departments of Internal Medicine and Physiology, Faculty of Medicine, University of Manitoba, Winnipeg, Canada
}

\begin{abstract}
Summary. Although growth hormone is known to be the main regulator of insulin-like growth factor-I, insulin has also been shown to play a role in regulating serum insulin-like growth factor I levels in diabetic animals. While this effect is thought to be due to correction of metabolic perturbations, some studies have suggest that insulin may have a direct effect on growth and/or insulin-like growth factor-I levels. We have examined the effects of acute and chronic insulin administration to non-diabetic, pituitary-intact and hypophysectomised rats. Rats were injected intraperitoneally with insulin as an acute bolus $(10 \mathrm{U})$ or a chronic subcutanious infusion (low dose; $2.4 \mathrm{U} /$ day, high dose; $12 \mathrm{U} /$ day) over 5 days. Insulinlike growth factor-I mRNA was quantitated by Northern and slot blots of RNA from various tissues. A small (less than 2fold) but significant increase $(p<0.05)$ was seen in hepatic insulin-like growth factor-I mRNA abundance in pituitary-intact rats following acute insulin injection and chronic low dose insulin infusion. An increase in insulin-like growth fac-
\end{abstract}

tor-I mRNA levels was also seen in other tissues including diaphragm, lung, kidney and heart. A significant increase $(p<0.05)$ in serum insulin-like growth factor-I levels was also observed $6 \mathrm{~h}$ after insulin injection. In contrast, in pituitary-intact rats which received high dose insulin infusion and were hypoglycaemic at the time of death, tissue levels of insulin-like growth factor-I mRNA were reduced compared to salinetreated control groups. Similarly in the hypophysectomised rats neither acute nor chronic insulin administration had any consistent effect on insulin-like growth factor-I mRNA abundance in any of the tissues examined. This data suggests that insulin has no direct effect in regulating insulin-like growth factor-I gene expression. The small effects demonstrable in pituitary-intact rats may result from a synergistic action of insulin with growth hormone or other pituitary factors.

Key words: Growth hormone, insulin, insulin-like growth factor-I, diabetes, growth, somatomedin.
Both clinical studies and studies in experimental animals have established that growth hormone $(\mathrm{GH})$ promotes the generation of circulating somatomedin activity in GH deficient states [1, 2]. Insulin-like growth factor-I (IGF-I) accounts for the majority of plasma somatomedin bioactivity [2]. Since IGF-I can mimic the growth promoting effect of $\mathrm{GH}$ in the hypophysectomised (hypox) rat, IGF-I is thought to mediate many of the actions of GH on its target tissues [3]. $\mathrm{GH}$ is the major regulator of circulating IGF-I levels and is thought to be the main, but not the only regulator of tissue IGF-I expression $[4,5]$. The finding of normal levels of IGF-I and catch-up growth in children with low or absent $\mathrm{GH}$ responses to stimulatory tests following craniopharyngeoma removal [6] suggests that factors other than GH may be important in normal growth. While both cortisol and thyroxine in addition to GH have been found to be necessary to normalise growth in hypox animals [7], clinical observations suggest that insulin also may play a role in regulating IGF-I. Poor growth and short stature with low IGF-I and normal or elevated GH levels have been reported in the poorly controlled diabetic child [8]. Improvement in growth and normalisation of plasma IGF-I levels accompanies improved blood sugar control [8]. Furthermore, normal growth and IGF-I levels can be achieved in the presence of suppressed $\mathrm{GH}$ levels in obese, hyperinsulinaemic individuals $[9,10]$.

In the streptozotocin-treated, diabetic rat, circulating IGF-I levels are significantly reduced in untreated animals and return to normal after institution of insulin therapy [11]. However, it is not clear whether this effect is a direct effect of insulin on IGF-I expression or a consequence of normalisation of hypothalamic-pituitary $\mathrm{GH}$ and somatostatin interactions. Griffen et al. have recently provided evidence that insulin delivered via the portal circulation is more potent than systemic insulin 

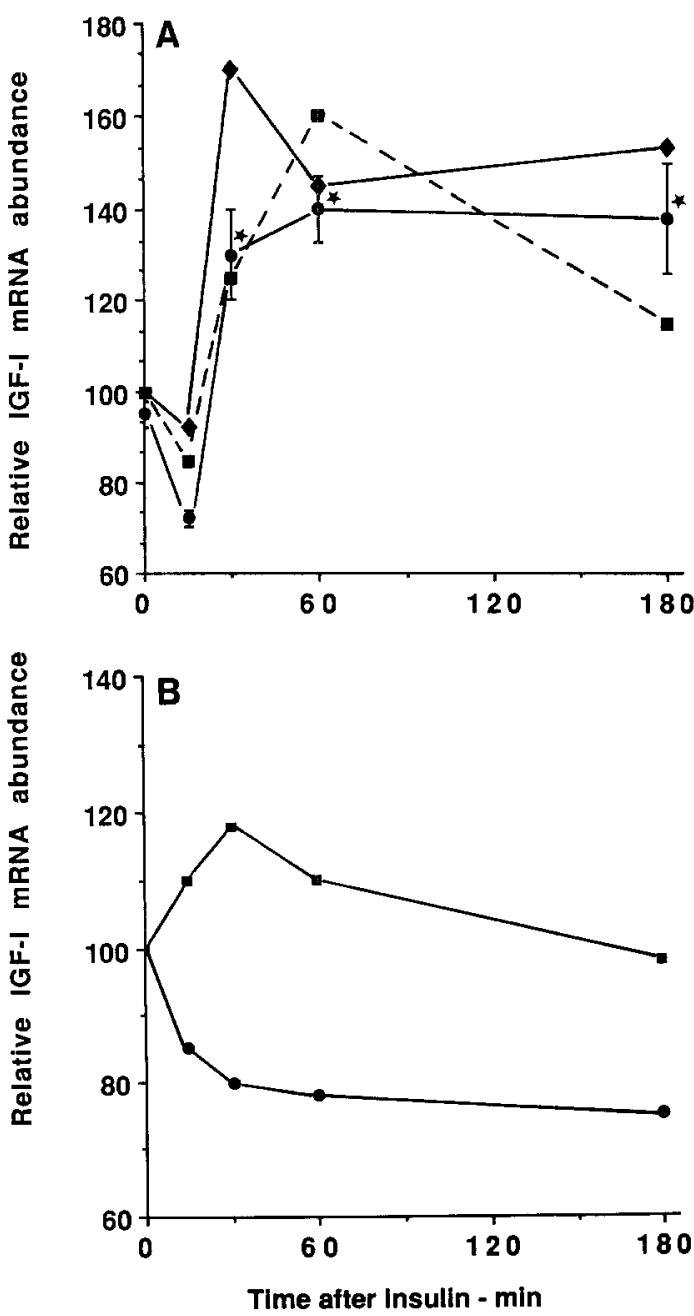

Fig.1. Changes in IGF-I mRNA abundance in various tissues of pituitary-intact rats killed at various times after a single i.p. injection of insulin. The changes in IGF-I mRNA abundance, quantitated by densitometry of autoradiograms of Northern blots and slot-blots, in RNA from the lung ( ), diaphragm $\square$ and liver (O) are shown in panel A. In panel B, the results obtained with RNA extracted from heart $\square$ and kidney ( $)$ are depicted. Data represents the mean of repeated determinations on two or three pools of RNA for all tissues except the liver where the mean \pm SEM of individual rat liver samples $(n=5)$ is depicted. Relative expression of IGF-I has been expressed as a percentage of untreated control rats. * represents $p<0.05$ for the difference from $t=0$ control rats

in normalising growth in diabetic rats, suggesting a direct insulin action in the liver on IGF-I expression [12]. In vitro studies using rat hepatocyte monolayers $[13,14]$ or isolated perfused livers $[15,16]$ have demonstrated that insulin results in a dose-dependent release of immunoreactive and/or bioactive IGF-I from this organ. It remains unresolved as to whether insulin has any direct effects on hepatic IGF-I mRNA. Furthermore, there are no data which directly addresses the role of insulin in regulation of IGF-I expression in non-hepatic tissue where IGF-I may have important autocrine or paracrine actions [17].

In this study, we have utilised RNA blot hybridisation to examine the effect of acute and chronic ad- ministration of insulin to non-diabetic pituitary-intact and hypox rats on IGF-I expression in hepatic and nonhepatic tissues.

\section{Materials and methods}

\section{Animals}

Adult female Sprague-Dawley rats, 60-65 days of age were obtained from the University of Manitoba breeding facility (Winnipeg, Canada). Hypox male rats were purchased from Charles River Canada (St.Constance, Quebec, Canada) and acclimatised in holding cages for approximately 1-2 week. Only rats which fullfilled the criteria previously established in this laboratory were considered hypophysectomised [18]. All rats in each study were allowed water and food ad libitum.

\section{Acute studies}

Groups of 5 pituitary-intact or hypox rats received a single i.p. injection of 10 units of regular insulin (Connaught Novo, Novo Industries, Toronto, Ontario, Canada, human insulin) and were killed 15, 30, 60 or $180 \mathrm{~min}$ after injection. Some rats were also killed $360 \mathrm{~min}$ after insulin injection for determination of serum glucose, GH and IGF-I. Control rats received an equivalent volume of saline and were killed within $1 \mathrm{~h}$ after injection. In addition to insulin, hypox rats received $0.5 \mathrm{ml}$ of $5 \%$ dextrose solution i.p. to prevent hypoglycemia. In these hypox rats only the liver was analysed for IGF-I mRNA and no determinations of serum glucose or IGF-I were made.

\section{Chronic studies}

Alzet minipumps (Alzet, No 2001, Palo Alto, Calif., USA) were implanted under ketamine anaesthesia $(250 \mathrm{mg} / \mathrm{kg})$ in the dorsal subcutaneous tissue of hypox or pituitary-intact rats. All rats received an i.p. injection of $0.5 \mathrm{ml}$ of $5 \%$ dextrose following implanation of the pump. Pituitary-intact rats which received insulin were implanted with pumps which delivered either a low-dose of insulin, $2.4 \mathrm{U} /$ day (U 100 Connaught Novo) or a higher dose of insulin, $12 \mathrm{U} /$ day (U 500, Connaught Novo). In the chronic insulin study where hypox rats were utilised, only the lower dose insulin pumps were used. Control, pituitary-intact or hypox rats were implanted with pumps filled with saline and otherwise treated in an identical fashion to animals implanted with insulin pumps. A group of sham-operated, but not pump-implanted hypox rats were also included, however, these animals did not differ significantly from saline-pump animals and data from this group of rats has been grouped together with the saline pump hypox rats. Of the 8 hypox rats implanted with insulin pumps, 3 were found dead on the second or third day after surgery. There were no deaths in the pituitary-intact rats or hypox rats which were sham-operated or which were implanted with saline containing pumps. All animals were killed after 5 days, and body weight, serum glucose, GH and IGF-I levels were determined.

\section{RNA Extraction and hybridisation}

RNA was extracted using the guanidium isothiocyanate/cesium chloride technique [19] from pooled organs (2-10 per preparation) except for the liver where individual rat liver samples were processed separately. Where stated, total cellular RNA was enriched for poly $(\mathrm{A})^{+}$RNA by a single cycle of oligo(dT)-cellulose affinity chromatography [20]. RNA was analysed by electrophoresis in a $1 \%$ agarose 
formaldehyde gel and transferred to nitrocellulose filters. In addition, each RNA sample was also analysed by slot-blot hybridisation. All RNA samples were analysed on at least two separate occasions. Filters were hybridised as previously described [18] with rat IGF-I cDNA labelled by nick-translation to a specific activity of approximately $10^{8}$ $\mathrm{dpm} / \mathrm{ug}$ DNA. This cDNA probe recognises all variant IGF-I mRNA so far described. Filters were also hybridised with a $28 \mathrm{~s}$ ribosomal probe as a control for gel loading [21]. Multiple autoradiograms of varying exposure duration were analysed by densitometry. Signal intensity was expressed as a percentage of control. The initial slope of the relationship between signal intensity and RNA applied was used for quantitation of slot-blot hybridisations as previously described [22].

\section{Glucose and hormone assays}

Serum glucose concentrations were measured using a glucose oxidase system (Sigma, St. Louis, Mo, USA). Serum GH was measured by radioimmunoassay. IGF-I concentrations were measured in acidethanol extracts of serum by a specific double antibody radioimmunoassay. Reagents were supplied by the National Hormone and Pituitary Program, (Baltimore, Md, USA). IGF-I results are expressed as $\mathrm{U} / \mathrm{ml}$ where 1 unit is equivalent to $940 \mathrm{ng}$ of human recombinant IGF-I (Amgen Biologicals, Thousand Oaks, Calif, USA). The sensitivity and precision of these assays has been previously reported [18].

\section{Statistical analysis}

Data are expressed as the mean \pm SEM. Student's $t$-test was used to determine the significance of differences between control and treated groups.

\section{Results}

Acute administration of insulin to pituitary-intact rats resulted in a significant fall in serum glucose concentration within $30 \mathrm{~min}$ and reached a nidir at $3 \mathrm{~h}$ after injection $(1.4 \pm 0.1 \mathrm{mmol} / 1)$. Although serum glucose fell, there was no significant changes in GH following insulin injection. IGF-I levels were significantly elevated $6 \mathrm{~h}$ after insulin injection $(1.22 \pm 0.22$ vs $0.67 \pm 0.08 \mathrm{U} / \mathrm{ml}, p<0.005$ ). When the relative abundance of IGF-I mRNAs was quantitated from either Northern blots (data not shown) or slot-blot hybridisation experiments there was a small but significant increase $(p<0.05)$ in hepatic IGF-I mRNA abundance (Fig. 1). Similarly, an increase in IGF-I mRNA was apparent in the lung and diaphragm, however, the magnitude of the increase was small with a less than two-fold increase in IGF-I mRNA after acute bolus injection of insulin (Fig. 1).

Since acute administration of insulin had little effect on IGF-I mRNA abundance, we next examined the effect of chronic insulin administration. Rats given a continous subcutaneous insulin infusion of $0.1 \mathrm{U} / \mathrm{h}$ had serum glucose, GH and IGF-I levels which were not significant different from animals implanted with saline containing pumps. In all tissues examined, the abundance of IGF-I mRNA in the insulin treated rats
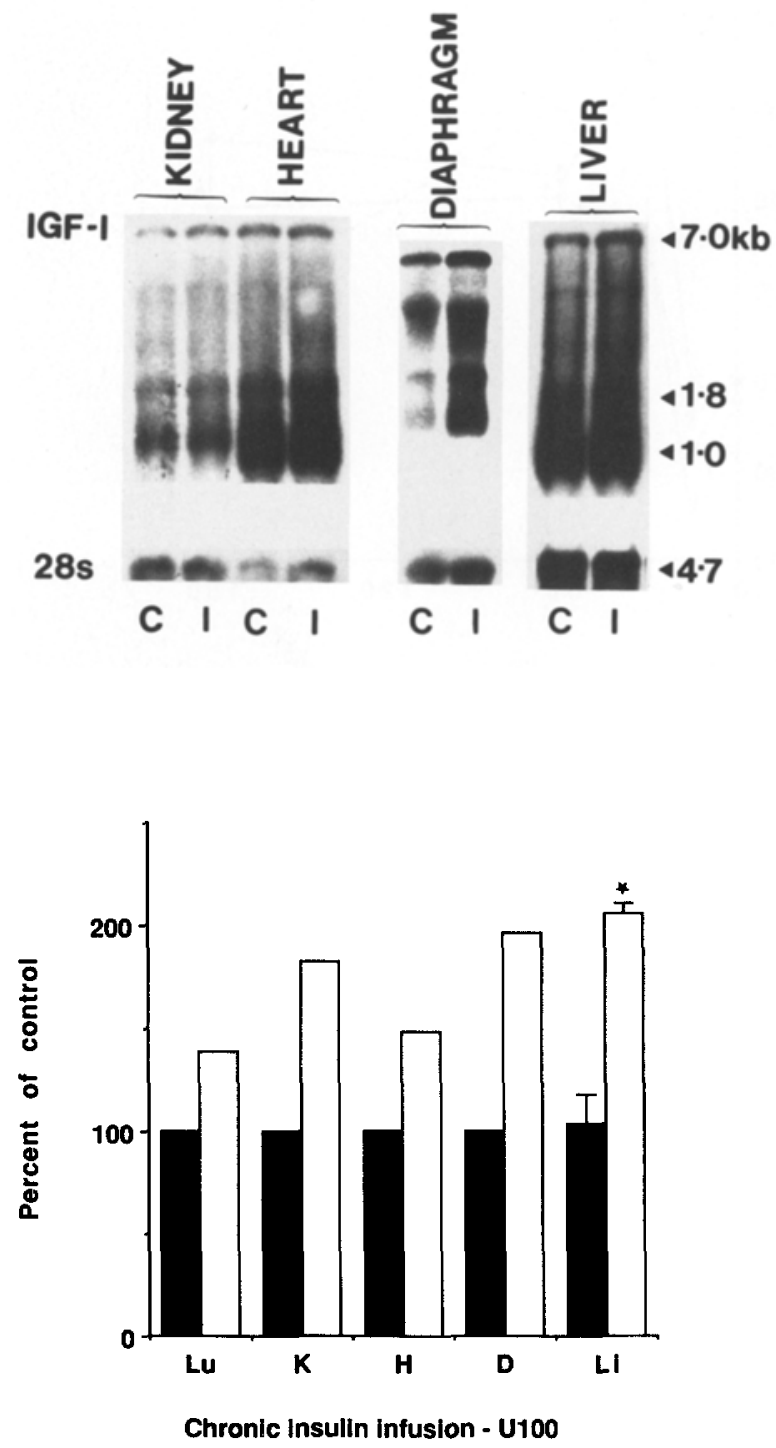

Fig. 2. The effect of chronic insulin administration on IGF-I mRNA abundance in pituitary-intact rats. The upper panel depicts representative autoradiograms of Northern blots from various tissues. Ten to 15 ug of poly $\left(\mathrm{A}^{+}\right)$RNA from saline infused control rats $(\mathrm{C})$ or insulin infused ( $2.4 \mathrm{U} /$ day) rats (I) were loaded per lane. Blots were hybridised with rat IGF-I cDNA and subsequently with a 28 s probe. The size of the major IGF-I transcripts is shown. In the lower panel, data from Northern and slot blot analysis have been quantitated by densitometry. The mean \pm SEM for 5 separate individual liver samples is shown while data from other tissues represent the mean of two separate pools of RNA from saline-infused animals (solid histograms) or insulin-infused rats analysed on 3 or more separate occasions. * represents $p<0.05$ for the difference between insulin infused and control rats

was increased compared to saline control rats, however, the increase was small in magnitude with the maximum increase of approximately 2 -fold occuring in the liver and diaphragm (Fig.2). In the liver, where it was possible to quantitate IGF-I mRNA abundance in individual rat samples, the difference between insulin and saline treated rats was statistically significant, $p<0.05$ (Fig. 2).

To further characterise the effect of chronic insulin administration on IGF-I expression, normal rats were 


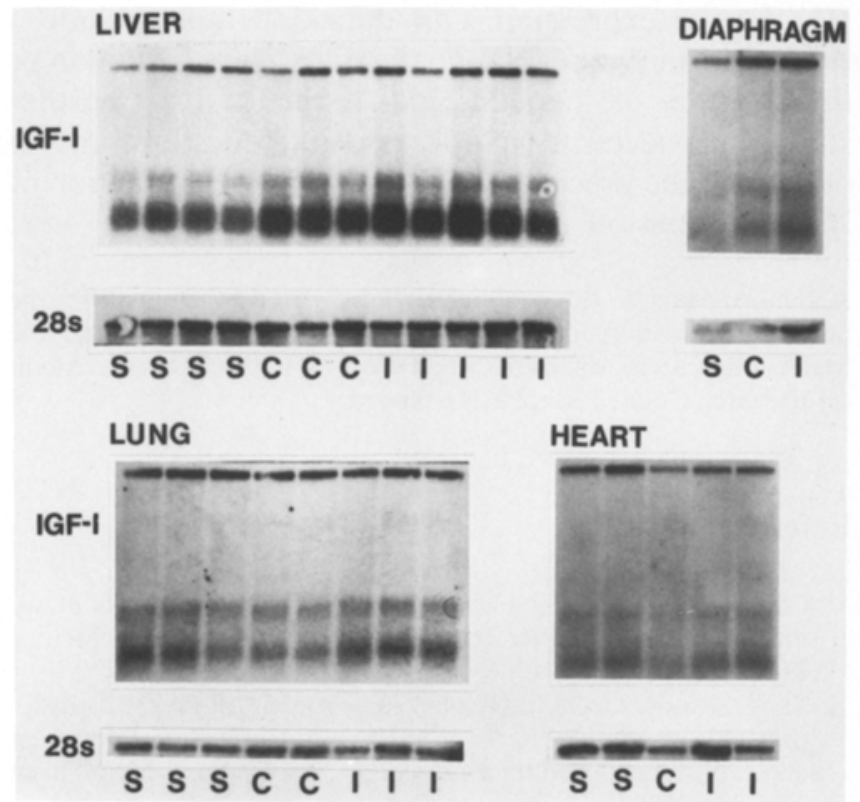

Fig.3. The effect of chronic insulin infusion on tissue IGF-I mRNA accumulation in hypophysectomised rats. Representative autoradiograms of Northern blots from sham-operated (S), saline-infused control (C) and insulin infused (I) rats are shown. Poly $\left(\mathrm{A}^{+}\right)$RNA, 10-20 ug from individual rat liver samples or tissue pooled from 3-7 rats was loaded per lane. Filters were hybridised with rat IGF-I cDNA and subsequently with a 28 s ribosomal probe

exposed to supraphysiological doses of insulin $(0.5 \mathrm{U} / \mathrm{h})$ over 5 days. This infusion of insulin produced a significant decrease in serum glucose $(1.7 \pm 0.5$ vs $5.3 \pm 0.1 \mathrm{mmol} / 1, p<0.005)$ and a significant increase in body weight $(228.0 \pm 4.6$ vs $191.3 \pm 4.3 \mathrm{~g}, p<0.005)$ at the time of death. Autoradiograms of Northern blots of RNA extracted from various tissues showed only small non-significant differences in the abundance of IGF-I mRNAs in various tissues (data not shown). No consistent increase in IGF-I mRNA abundance was seen in any of the tissues examined. On the contrary in these insulin-treated rats, most tissues demonstrated a decrease in abundance of IGF-I transcripts. This decrease was

Table 1. The effect of insulin on body weight, serum glucose and insulin-like growth

\begin{tabular}{lll}
\hline & \multicolumn{2}{l}{ Factor-I concentration in hypophysectomised rats } \\
\cline { 2 - 3 } & Control rats ${ }^{\mathrm{a}}$ & Insulin-treated rats \\
\hline $\begin{array}{l}\text { Number } \\
\text { Body weight } \\
\text { gain (grams) }\end{array}$ & 10 & 5 \\
$\begin{array}{l}\text { Glucose } \\
\text { (mmol/1) }\end{array}$ & $6.18 \pm 0.40$ & $5.66 \pm 0.55^{\mathrm{c}}$ \\
$\begin{array}{l}\text { IGF-I } \\
(\mathrm{U} / \mathrm{ml})\end{array}$ & $0.043 \pm 0.011$ & $6.39 \pm 0.42$ \\
\hline
\end{tabular}

a Sham-operated rats $(n=7)$ and saline pump rats $(n=3)$ have been considered as a single group; ${ }^{b}$ Body gain was calculated after substraction of implanted pump weight; ${ }^{c}$ indicates $p<0.05$ for the differences between insulin-treated and control rats most marked in hepatic, pulmonary and adipose tissues.

To determine whether subtle perturbations in endogenous $\mathrm{GH}$ release may be masking insulin effects on tissue IGF-I expression, we examined the effects of acute and chronic administration of insulin to hypox rats. In the acute insulin study with hypox rats, it was necessary to simultaneously administer dextrose to prevent hypoglycaemia; therefore, no determinations of serum glucose were made. In these hypox rats, acute administration of insulin had no consistent effect on the abundance of hepatic IGF-I mRNA.

In hypophysectomised rats which were implanted with insulin containing minipumps, a significant increase $(p<0.05)$ in body weight gain was seen (Table 1 ). This was consistent with the increased amount of adipose tissue apparent at the time of death in these animals. Serum IGF-I and glucose concentrations were not significantly different from the control rats in hypox rats implanted with insulin-pumps. Autoradiograms of Northern blots of RNA from hypox rats infused with insulin and saline are shown in Figure 3. No consistent differences in tissue IGF-I mRNA levels were found between sham-operated control rats, saline-pump control rats and insulin-pump treated hypox rats.

\section{Discussion}

Several mechanisms to account for the apparent growth promoting effects of insulin have been proposed. In vitro studies have demonstrated that insulin may act via the type 1 IGF receptor [23] or less commonly via its own receptor [24] to exert a mitogenic response [23]. Insulin action via the type 1 IGF receptor is only observed at micromolar concentrations, concentrations which are unlikely to be encountered in vivo. In addition to these direct mechanisms, insulin may potentiate the action or enhances the local synthesis of growth factors including the IGFs. Furthermore, insulin may increase the number of GH receptors in target tissues [25] or potentiate GH signal transduction at some post-receptor step [11] and in this way increase IGF-I synthesis.

Poorly controlled diabetic animals have low circulating somatomedin levels and treatment with insulin increases IGF-I levels and results in growth [26-28]. This observation is supported by in vivo studies where increasing amounts of insulin added to perfused rat livers results in an increase in somatomedin activity in the perfusate $[13,15,16]$. However, Schalch et al. found no increase in IGF-I levels in the perfusate of normal rat levels despite the use of pharmacological doses of insulin [7] suggesting that in the non-diabetic situation insulin may have little effect on hepatic IGF-I expression.

Early studies in hypox rats demonstrated that insulin did stimulate both body weight gain and axial growth in hypox rats although the effect was predomi- 
nantly to increase adiposity [29]. Clinical observations also suggest that insulin may be important in skeletal growth. Growth, despite apparent growth hormonedeficiency has been reported in obese, hyperinsulinaemic children $[6,9]$ and poor growth despite high $\mathrm{GH}$ concentrations and low insulin occurs in some cases of protein-calorie malnutrition [30]. These observations suggests that insulin may have direct growth effects or potentiate the effect of very low levels of circulating GH.

In this study, we have examined the effect of insulin on hepatic and non-hepatic IGF-I gene expression in both normal and hypophysectomised nondiabetic rats. An acute injection of insulin had no significant effect on hepatic IGF-I mRNA abundance in hypox rats; however, a small increase in IGF-I mRNA was seen $1-3 \mathrm{~h}$ after insulin injection in the liver, lung and diaphragm of pituitary-intact rats. A significant increase in circulating IGF-I was also apparent $6 \mathrm{~h}$ after insulin injection. Similarly, in pituitary-intact rats which were implanted with pumps which delivered the lower insulin dose a small increase in IGF-I mRNA abundance was seen in many tissues. Since it was necessary to pool non-hepatic tissues to obtain sufficient RNA, it is not possible to determine whether these small difference in IGF-I expression were statistically different. The higher insulin infusion rate in normal rats was not accompanied by increase in tissues IGF-I mRNA. However, these animals were hypoglycaemic at the time of death and the counterregulatory response (e.g. cortisol) may itself have effects on GH-IGF-I signal transduction. Alternatively, chronic hyperglycaemia may suppress pituitary $\mathrm{GH}$ release in the rat, since acute hypoglycaemia in the rat in contrast to man suppresses rather than stimulates GH release [31]. In addition to any effect insulin has on IGF-I gene expression, insulin may also effect clearance of IGF-I from the circulation by an effect on IGF binding proteins [32]. This mechanism may explain the apparent discordance between changes in hepatic IGF-I mRNA and serum IGF-I concentrations in insulin-infused pituitary-intact rats.

In the hypox rat, insulin had no effect on tissue IGFI mRNA levels suggesting that the insulin effect on IGF-I involves synergism with a pituitary factor such as GH. The hypox rats which were implanted with insulin pumps were significantly heavier $(p<0.05)$ that control sham-operated or saline-infused rats. These rats were not hypoglycaemic at the time of death. However, it is possible that they were hyperglycaemic at some stage throughout the 5 day study period since 3 out of 8 hypox rats implanted with insulin pumps did not survive the 5 days of the study.

The data presented here suggest that insulin has little, if any, direct effect on regulating IGF-I mRNA abundance in the tissues of the non-diabetic rats. However, insulin may potentiate the action of GH or some other pituitary factors involved in the regulation of
IGF-I gene expression. Our data does not exclude a role for insulin in regulating the translation, secretion or degradation of hepatic and tissue IGF-I. Further studies are necessary to address these questions and to determine the precise role of insulin in GH induction of IGF-I expression.

Acknowledgements. This research was supported by grants from the Sellar's Foundation, the Canadian Diabetes Association and the Medical Research Council of Canada. L.J.M. is a recipient of a Medical Research Council Scholarship Award.

\section{References}

1. Chochinov RH, Daughaday WH (1976) Current concepts of somatomedin and other biologically related growth factors. Diabetes 25: 994-1004

2. Zapf J, Rinderknecht E, Humbel RE, Froesch ER (1978) Nonsuppressable insulin-like activity (NSILA) from human serum: recent accomplishments and their physiologic implications. Metabolism 27: 1803-1828

3. Schoenle E, Zapf J, Hauri CH, Steiner TH, Froesch ER (1985) Comparison of in vivo effects of insulin-like growth factor I and II and of growth hormone in hypophysectomized rats. Acta Endocrinol 108: 167-174

4. Murphy LJ, Murphy LC, Friesen HG (1988) Estrogen induces insulin-like growth factor-I expression in the rat uterus. Mol Endocrinol 1: $445-450$

5. Francis MJO, Hill DJ (1983) Prolactin-stimulated production of somatomedin by rat liver. Nature 255: 167-168

6. Kenny FM, Iturzaeta NF, Mintz D, Drash A, Garces LY, Susen A, Askari HA (1968) Iatrogenic hypopituitarism in craniopharyngioma: unexplained catch-up growth in three children. J Pediatr 72: 766-775

7. Schalch D, Heinrich U, Draznin B, Johnson C, Miller L (1979) Role of the liver in regulating somatomedin activity: hormonal effects on the synthesis and release of insulin-like growth factor and its carrier protein by the isolated perfused rat liver. Endocrinology 104: 1143-1151

8. Winter RJ, Phillips LS, Green OC, Traisman HS (1980) Somatomedin activity in the Mauriac syndrome. J Pediatr 97: 598-600

9. Costin G, Kogut MD, Phillips LS, Daughaday WH (1976) Craniopharyngioma: the role of insulin in promoting postoperative growth. J Clin Endocrinol Metab 42: 370-375

10. Copinschi G, Wegienka LC, Hane S, Forsham PH (1967) Effect of arginine on serum levels of insulin and growth hormone in obese subjects. Metabolism 16: 485-491

11. Maes M, Ketelslegers J-M, Underwood LE (1983) Low plasma somatomedin-c in streptozotocin-induced diabetes mellitus. Correlation with changes in somatogenic and lactogenic liver binding sites. Diabetes 32: 1060-1069

12. Griffen SC, Russel SM, Katz LS, Nicole CS (1987) Insulin exerts metabolic and growth promoting effects by a direct action on the liver in vivo: clarification of the functional significance of the portal vascular link between the beta cells of the pancreatic islets and the liver. Proc Natl Acad Sci USA 88: 7300-7304

13. Kogawa M, Takano K, Asakawa K, Hizuka N, Tsushima T, Shizume K (1983) Insulin stimulation of somatomedin A production in monolayer cultures of rat hepatocytes. Acta Endocrinol 108: 1265-1271

14. Scott CD, Baxter RC (1986) Production of insulin-like growth factor $I$ and its binding protein in rat hepatocytes cultured from diabetic and insulin-treated diabetic rats. Endocrinology 119: 2346-2352

15. Miller L, Schalch D, Draznin B (1981) Role of the liver in regulating somatomedin activity: effects of streptozotocin diabetes and starvation on the synthesis and release of insulin-like growth fac- 
tor and its carrier protein by the isolated perfused rat liver. Endocrinology 108: 1265-71

16. Daughaday W, Phillips L, Mueller M (1976) The effects of insulin and growth hormone on the release of somatomedin by the isolated rat liver. Endocrinology 98: 1214-1219

17. D'Ercole AJ, Stiles AD, Underwood LE (1984) Tissue concentrations of somatomedin C: further evidence for multiple sites of synthesis and paracrine or autocrine mechanisms of action. Proc Natl Acad Sci USA 81: 935-941

18. Murphy LJ, Bell GI, Duckworth ML, Friesen HG (1987) Identification, characterization and regulation of a rat cDNA which encodes insulin-like growth factor-I. Endocrinology 121: 684-691

19. Chirgwin J, Pryzbyla A, MacDonald R, Rutter W (1979) Isolation of biologically active ribonucleic acid from sources enriched for ribonuclease. Biochemistry 18: 5294-5299

20. Aviv H, Leder P (1972) Purification of biologically active globin messenger RNA by chromatography on oligothymidylic acid-cellulose. Proc Natl Acad Sci USA 69: 1408-1412

21. Gonzalez IL, Gorski JL, Campen TJ, Dorney DJ, Erickson JM, Sylvester JE, Schmickel RD (1985) Variation among human 28S ribosomal RNA genes. Proc Natl Acad Sci USA 82: 7666-7670

22. Murphy LJ, Friesen HG (1988) Differential Effects of estrogen and growth hormone on uterine and hepatic insulin-like growth factor-I gene expression in the ovariectomized hypophysectomised rat. Endocrinology 122: 325-332

23. King GL, Kahn CR, Rechler MM, Nissley SP (1980) Direct demonstration of separate receptors for growth and metabolic activities of insulin and multiplication-stimulating activity (an insulinlike growth factor) using antibodies to the insulin receptor. J Clin Invest $66: 130-140$

24. Koontz JW, Iwahashi M (1981) Insulin as a potent, specific growth factor in a rat hepatoma cell line. Science 211: 947-949

25. Baxter RC, Bryson JM, Turtle JR (1980) Somatic receptors of rat liver: regulation by insulin. Endocrinology 107: 1176-1181
26. Phillips LS, Young HS (1976) Nutrition and somatomedin II. Serum somatomedin activity and cartilage growth activity in streptozotocin-diabetic rats. Diabetes 25: 516-527

27. Takano K, Hizuka N, Shizume K, Hasumi Y, Kogawa M, Tsushima $T$ (1980) Effect of insulin and nutrition on serum levels of somatomedin A in the rat. Endocrinology 107: 1614-1619

28. Taylor AM, Sharma AK, Avasthy N, Duguid IGM, Blanchard DS, Thomas PK, Dandona P (1987) Inhibition of somatomedin-like activity by serum from streptozotocin-diabetic rats: Prevention by insulin treatment and correlation with skeletal growth. Endocrinology 121: 1360-1365

29. Salter J, Best CH (1953) Insulin as a growth hormone. Br Med J 2: $353-356$

30. Grant DB, Hambley J, Becker D, Pimstone BL (1973) Reduced sulfation factor in undernourished children. Arch Dis Child 48: 569-600

31. Takahashi K, Daughaday WH, Kipnis DM (1971) Regulation of immunoreactive growth hormone secretion in male rats. Endocrinology 88: 909-917

32. Busby WH, Snyder DK, Clemmons DR (1988) Radioimmunoassay of a 26,000-dalton plasma insulin-like growth factor-binding protein: control by nutritional variables. J Clin Endocrinol Metab 67: $1225-1230$

Received: 14 September 1988

and in revised form: 4 April 1989

Dr. L.J. Murphy

Room 435, Basic Medical Science Building

University of Manitoba

770 Bannatyne Avenue

Winnipeg, Manitoba, R3E 0W1

Canada 